\title{
Gender Based Injustice in Mahesh Dattani’s Tara
}

\author{
D. Brindha, Usha. M, Manisha. P. K, Maria Faustina. B
}

\begin{abstract}
The paper is an endeavour to inspect the sex based unfairness in Tara by Mahesh Dattani. Mahesh Dattani, the well-known dramatist had tested the development of India exhibited in the advanced English Theatre. Tara manages the muddle elements of present day urban family in India of Gender separation. This present paper is a humble endeavours of underestimation of ladies. As the play courses through the conjoined twins of Tara and Chandan and lights up the male inclination over the female one. The play portrays the inescapability and profound rootedness of the general public.

The ladies go about as device for the mistreatment and helpless against separation of these qualities disguised. Bharathi's (the mother) support over the male kid, made the other one injured and she experiences the blame all through. Both being distinctively abled Tara was going to confront the twofold underestimation in the general public of concentrated disposition individuals. Abuse of science and innovation has been appeared through the character Dr.Thakkar.

Through his plays, Dattani utilizes Indian folklore, ceremonies, convention and contemporary issues. The plays of Dattani have a general intrigue. They could be stayed anyplace on earth, they would draw the complete consideration of the group. Striking topic and strange style has been pulled in the peruses. Tara tends to the subject of sexual orientation, however not really cliché generalizations of predisposition against young lady youngster, despite the fact that that is commonly acknowledged translation of the play in India.
\end{abstract}

\section{INTRODUCTION}

Mahesh Dattani being described as one of the India's best and most serious contemporary playwrights in English has won Sahitya Akademi Award for Find Solutions and Other Plays in 1978. Through his plays, Dattani makes an abundant use of Indian mythology, rituals, traditions and contemporary problems. The plays of Dattani have a universal appeal. They would be staged anywhere on earth, they would draw the full attention of the crowd, bold theme and unusual style has been attracted the readers. Tara addresses the question of gender, though not necessarily bond stereotypes of bias against the girl child, although that is generally accepted interpretation of the play in India.

\section{GENDER BASED INJUSTICE \& RESULTS}

Tara lays everything out in London. Dan (Chandan), the favored kid youngster stated,

\section{Revised Manuscript Received on September 14, 2019.}

D. Brindha, AUTHOR, Assistant Professor, Department of English, Sri Krishna Arts and Science College, Kuniamuthur, Coimbatore, Tamilnadu, India.

Usha. M, CO-AUTHOR, Assistant Professor, Department of English, Sri Krishna Arts and Science College, Kuniamuthur, Coimbatore, Tamilnadu, India.

Manisha. P. K, CO-AUTHOR, II M.A. English Literature, Sri Krishna Arts and Science College, Kuniamuthur, Coimbatore, Tamilnadu, India.

Maria Faustina. B, CO-AUTHOR, II M.A. English Literature, Sri Krishna Arts and Science College, Kuniamuthur, Coimbatore, Tamilnadu, India.

\section{Truly I have recollections.}

I continue gazing at my consistently,

Thinking about how best to transform my anguish into dramatization.

Tara sets out the passionate division that develops between the two conjoined twins and their physical partition made by her mom scrutinized the extraordinary likelihood of the endurance of the young lady. Chandan had even overlooked that he had a twin sister, until he thought of her as the topic for his next artistic endeavor. Dattani has displayed the unusual truth of the ladies playing trick to man. It is about the boldness and the soul over the disabled young lady youngster, conceived in Gujarati family.

Tara, also, perhaps we are as yet like we have consistently been. Indivisible, the manner in which we began throughout everyday life. Two lives in a single body in one agreeable belly. Till we are constrained out.

The movement that he appears to guarantee is that normally manliness and womanliness are portions of personality of a person. Dattani himself referenced in one of his meetings with Lakshmi Subramaniyam, Dattani considers Tara to be a play about the male self and female self. "The male self is being set up in all societies where female self isn't".

In Tara, Patel's family is financially and politically very stable.

The men in the house were choosing

Whether they will go chasing while the ladies took care of the cavern.

This explanation claims out if Tara had endured further more.

During the social development of sexual orientation, stereotyped sex jobs assume a significant job while the male jobs are viewed as viable. Based on the predominance of the jobs, Patel asks Chandan to help him in business and anticipates that Tara should stay in residential environment. Chandan is keen on alleged female jobs where he wants to be, where it is Tara who appears to be progressively disposed to go into a profession like her dad. In a man centric culture, incomprehensibly ladies, assume a significant job in sustaining victimization men. Bharathi, a lady supports the young lady kid during medical procedure.

Indeed, even her mom Bharathi picks over Tara to Chandan, and all things considered regardless of whether a young lady doesn't pick over a young lady who else will pick over a young lady? 
This demonstrates, the male centric structure, the qualities based towards male are profoundly disguised even by the female Psyche through social molding. So in male controlled society a lady turns into a device against other ladies in an endless loop. Patel uncovers the mystery about choice with respect to medical procedure.

A sweep indicated that a significant piece of the blood supply to the third leg was given by the young lady. Your mom requested a reconfirmation. The outcome was the equivalent. The odds were better that the leg would get by on the young lady. Your granddad and mom had a private gathering with Dr.Thakkar. I wasn't approached to come, a similar night your mom let me know of her choice. I couldn't accept what she revealed to me that they would give the two legs to the kid. Possibly I had fought all the more emphatically.

This is a significant leap forward of the play. After the disappointment of medical procedure, Bharathi brimming with blame as she has grabbed the life of her little girl. She attempts to beat the blame like,

Truly I plan for her satisfaction, I intend to give her everything the friendship I intend to give her. It's what she deserves. Love can compensate for a ton.

She attempts to decrease her blame by moving fault to her significant other and giving that she loves Tara more than he does. Patel comments:

You realize she cherishes you. You're certain about that. Try not to cause her to pick between us, for the good of god!

Roopa is another choice made by Bharathi and completely refuted it. She even fixes Roopa to play with Tara. Roopa says that Tara's mom influenced her to be her companion, and made her to feel sorry for on her since she needs to give Roopa certain things, and now she has at long last gone insane.

Her blame drives her to madness. The sufferings and blame of Bharathi shows how ladies endure in male centric framework and qualities. Later when Tara leaves reality that she has separated by her mom, she is stunned and sincerely broken.

Dattani deconstructs the legend, that nature and God have made male better than female. He even attempts to state that male and female are equivalent according to nature and God, yet it is the male centric culture has misleadingly made sex imbalance. Dr. Thakkar speaks to the logical information which has additionally turned into an apparatus in the hands of patriarchs for mistreatment and oppression of ladies. Be that as it may, he considers sexual orientation disparity is unfeeling and exploitative. Dan considers shamefulness against Tara an unnatural sin:

She merits something better. She never got a reasonable arrangement. Not even from us. Neither of us did. God never needed us to be isolated. Fate, want and peculiar things. A duel to the passing among god and nature on the one side and on the other the astounding Dr. Thakkar.

In a male centric culture, the physical magnificence is esteemed more than her knowledge or internal excellence. Chandan feels second rate about his physical disfigurement. He feels they are not the monstrous one. We are repulsive one legged animals.
Notwithstanding, Tara is a solid and delicate young lady, drives her reluctant sibling to take an interest in standard society with certainty and show his value.

You are apprehensive .Afraid of meeting new individuals. Individuals who don't have any acquaintance with you. Who won't realize how shrewd you are. You are apprehensive they won't see past your.

The oppression ladies begin from the mother's belly. The occurrence of female foeticide and female child murder are regular in our general public. A young lady is viewed as weight on guardians monetarily, inwardly, and socially which prompts murder of young lady kid. The play delivers this point through Roopa's comments:

Since you exist, I will let you know. It may not be valid. Be that as it may, this what I have heard. The Patels in the past times were discontent with getting Girl babies; you know settlement and things like that so they used to suffocate in milk.

Dattani has insightfully utilized the staggered set in the plays. The specialty of portrayal is striking in his play. His characters appear to be real because of his profound comprehension of society and human brain research. This is one reason the group of spectators/peruses associated with his plays.

Mahesh Dattani plays have an assortment and his topics are of contemporary intrigue. He has isolated profound into the human heart and re-made character with genuineness and a feeling of energy.

\section{CONCLUSION}

Dattani has effectively consulted with the topic of sex, incapacity the group of self - respect in the play. Taking a strange subject of conjoined twins, he sensibly contacted different issues identified with sex separation. He introduces a harsh truth of society with being pedantic and contacts different subjects with delicate heart. The play effectively features the predicament of underestimated ladies in man centric culture in an unpretentious way. Dattani sees with the female side of our self in a world that consistently "What is Male", however numerous individuals in India consider it to be a play about the Girl youngster.

\section{REFERENCES}

1. Halder, Santwana. "Gender Discrimination in Mahesh Dattani's Tara: A Study of Prejudice in Patriarchal Society." The Dramatic World of Mahesh Dattani: A Critical Exploration (2006).

2. Babu,G. " Gender based injustices in Mahesh Dattani's Tara." International Journal of English and Literature. Web. 4 August 2014.

3. Rao, Dr Bolla Mallikharjuna, And Bolla Ramakrishna. "An International Peer-Reviewed Open Access Journal." (2015). 